\title{
Capitalism über alles: uma interpretação da pandemia de coronavírus no Brasil à luz da geografia radical de Neil Smith
}

Capitalism über alles: uma interpretação da pandemia de coronavírus no Brasil à luz da geografia radical de Neil Smith

Capitalism über alles : une interprétation de la pandémie de coronavirus au Brésil à la lumière de la géographie radicale de Neil Smith

Capitalism über alles: una interpretación de la pandemia de coronavirus en Brasil a la luz de la geografía radical de Neil Smith

Capitalism über alles: an interpretation of coronavirus pandemic in Brazil under the light of Neil Smith's radical Geography

\section{João Alves de Souza Neto e Fernando Molnar Castro}

\section{OpenEdition}

Journals

Edição electrónica

URL: http://journals.openedition.org/espacoeconomia/12104

DOI: 10.4000/espacoeconomia.12104

ISSN: 2317-7837

Editora

Núcleo de Pesquisa Espaço \& Economia

Refêrencia eletrónica

João Alves de Souza Neto e Fernando Molnar Castro, « Capitalism über alles: uma interpretação da pandemia de coronavírus no Brasil à luz da geografia radical de Neil Smith », Espaço e Economia [Online], 18 | 2020, posto online no dia 14 abril 2020, consultado o 20 maio 2020. URL : http:// journals.openedition.org/espacoeconomia/12104; DOI : https://doi.org/10.4000/espacoeconomia. 12104

Este documento foi criado de forma automática no dia 20 maio 2020

(c) NUPEE 


\section{Capitalism über alles: uma interpretação da pandemia de coronavírus no Brasil à luz da geografia radical de Neil Smith}

Capitalism über alles: uma interpretação da pandemia de coronavírus no

Brasil à luz da geografia radical de Neil Smith

Capitalism über alles : une interprétation de la pandémie de coronavirus au

Brésil à la lumière de la géographie radicale de Neil Smith

Capitalism über alles: una interpretación de la pandemia de coronavirus en

Brasil a la luz de la geografía radical de Neil Smith

Capitalism über alles: an interpretation of coronavirus pandemic in Brazil

under the light of Neil Smith's radical Geography

João Alves de Souza Neto e Fernando Molnar Castro

\section{Introdução}

No dia 11 de Março de 2020, o diretor-geral da Organização Mundial da Saúde, Dr. Tedros Adhanom Ghebreyesus, anunciou que a COVID-19, doença causada pelo novo coronavírus SARS-CoV-2, "pode ser caracterizada como uma pandemia." ${ }^{1}$ Isso indicou para o mundo que a doença possui vários focos epidêmicos em diversos países. Ele seguiu seu discurso dizendo que nós "nunca vimos antes uma pandemia iniciada por um coronavírus" (dado que os coronavírus anteriores, SARS-CoV e MERS-CoV, não atingiram grau pandêmico, somente epidêmico) e, logo em um momento seguinte, que nós também "nunca vimos antes uma pandemia que poderia ser controlada ao mesmo tempo." Menos de uma semana depois, o presidente dos EUA, Donald Trump, com a iminência dos EUA como epicentro da pandemia, afirmou que o coronavírus é, na sua realidade, um "vírus chinês"'. 0 presidente do Brasil, Jair Bolsonaro, seguiu essa fala ao 
iniciar seu discurso contra o isolamento social (método para contenção da disseminação do vírus pela população) falando que após "resgatarmos nossos irmãos em Wuhan, na China [...] surgiu para nós um sinal amarelo." ${ }^{3}$ Ambos os presidentes, identificados com movimentos de extrema-direita, atribuem ao vírus uma identidade estrangeira. Outros movimentos de extrema-direita atribuem ao vírus uma externalidade semelhante, apesar de serem mais explícitos na expectativa de genocídio advindo dele ${ }^{4}$. Não obstante o discurso racista e genocida da extrema-direita, que atribui ao vírus um caráter de força vinda de fora, não aparecer difundido na grande imprensa, esta atribui ao vírus o caráter de sujeito outro que age sobre a sociedade humana. Isso fica ainda mais evidente na imprensa que trata dos impactos econômicos advindos da pandemia ${ }^{5}$. Isto significa que o coronavírus é tomado como uma força outra não-humana, uma força natural que age sobre a sociedade humana.

2 Para contra-argumentar essa perspectiva que, em resumo, vê o desastre causado pelo coronavírus como um desastre natural ${ }^{6}$, colocando toda a sociedade como paciente da doença, apresentamos neste texto a crítica que o geógrafo Neil Smith (1954-2012) faz dessa perspectiva ideológica sobre os desastres sociais, perspectiva esta que transforma eventos naturais mediados pela sociedade em desastres naturais.

3 Neil Smith, em seu texto "There's no such thing as a natural disaster" (SMITH, 2006) ${ }^{7}$, ao tratar do Furacão Katrina ocorrido em 2005, elenca cinco aspectos (ou fases) importantes no processo de constituição de um desastre social advindo da presença de um evento natural. Ele escreve que "os contornos do desastre e a diferença entre quem vive e quem morre é em uma maior ou menor medida um cálculo social." É esse calculo social que gostaríamos de apresentar. Os aspectos que serão tratados ao longo do ensaio são os que seguem. Primeiro, as causas, isto é, as determinantes sociais para a ocorrência do evento natural e as determinações sociais para o reconhecimento desse evento. Segundo, as vulnerabilidades, quais são as partes da sociedade que estão mais suscetíveis ou menos suscetíveis à ocorrência de desastres e por quê. Terceiro, a preparação é outro aspecto importante, pois ela pressupõe a expectativa do desastre dada a própria realidade social. Isso implica no aspecto seguinte, quarto, resultados e resposta, que é a equação das fases anteriores em um novo aspecto e a ação diante dele. A fase terminal, que materializará o aprendizado dessa sociedade diante do desastre, é a fase de reconstrução, quinto aspecto. Essa análise servirá para desconstruir também a perspectiva de resolução desse problema social emergente, que invoca uma solidariedade de cunho nacionalista e belicista, e suspende os conflitos de classe, anulando a possibilidade de uma solidariedade radical e revolucionária.

4 A questão da solidariedade esbarra numa contradição já apontada por Neil Smith quando ele discute a globalização (SMITH, 1997): a escala de ação política já não condiz mais com a escala econômica. Ou seja, é impossível conter efetivamente uma pandemia se a ação política é restrita à escala nacional. Com a economia globalizada, mercadorias e capitais circulam para além da capacidade de ação política dos governos nacionais. $O$ vírus age da mesma forma: não há fronteiras ou barreiras capazes de detê-lo. A pandemia, tal qual a força inexorável da economia de mercado globalizada que expandiu qualquer fronteira, não é natural. Não obstante, faz-se necessário pensar ações políticas que possam extrapolar a escala nacional com vistas a garantir um sistema de saúde amplo, universal e de caráter mundial que possibilite contornar os problemas criados pela própria economia globalizada. Na contramão da solidarização, a ideologia neoliberal busca ampliar suas taxas de lucro ou, pelo menos, garantir a 
manutenção delas diante da atual crise do capitalismo - sobrevivência (do capitalismo) acima de tudo e de todos! Contraditoriamente, portanto, a globalização criou as barreiras de expansão do neoliberalismo justamente ao forçar sua expansão.

5 Nesse sentido, as Medidas Provisórias 927 e 928 são a expressão máxima da contradição acima mencionada. Diante da necessidade de se criar medidas eficazes na contenção da pandemia, o governo federal brasileiro edita duas Medidas Provisórias (MPs) atacando diretamente a classe trabalhadora, justamente a que mais sofrerá com as consequências da pandemia. Indo na contramão da solidariedade necessária para superar de modo eficaz esse momento tão crucial, as Medidas Provisórias prevêem acordos individuais entre os trabalhadores e os empregadores sob a justificativa de garantir o emprego e, assim, a economia do país. Ao contrário, como as MPs não fornecem qualquer garantia de segurança às empresas, elas serão obrigadas a buscar por seus próprios meios outros modos de sobreviver durante a pandemia e a crise. Obviamente, diante dessas possíveis perdas, as empresas aumentarão a taxa de exploração específica da força de trabalho (cf. MÉSZÁROS, 2011, pp. 69-71) e, assim, os trabalhadores precisarão, da mesma forma, encontrar novos modos de sobreviver. Todos os ataques à classe trabalhadora, que vinham se acumulando há anos, culminam-se em evidência com a chegada dessa pandemia. 0 coronavírus não é mero fenômeno da natureza, apenas mais um vírus, mas um problema para a sociedade brasileira, talvez o que mais concentra todos os outros.

\section{Processo de transformação de um evento natural em desastre social}

1) Causas: epidemias conhecidas, destruição de hábitats naturais e a globalização do Capital

6 A manifestação do primeiro caso de doença causada pelo novo coronavírus se deu, até onde se sabe, no final de Dezembro de 2019 em Wuhan, na República Popular da China. Ao monitorá-la, posteriormente descobriu-se que a doença, ainda sem causa determinada, havia sido causada por um vírus semelhante àquele que atingiu a China no começo do século XXI. Logo que esse vírus foi identificado como patógeno, uma série de conhecimentos prévios acumulados pode dar significado a esse novo vírus: uma epidemia estaria na iminência de ocorrer. Ao mesmo tempo em que a China instalou um sistema de contenção à circulação dos vetores do vírus (as próprias pessoas) e controle dos infectados mais especificamente, ele foi espalhado pelo globo, tornando a epidemia local em uma pandemia global, assim como os cientistas que avaliavam o caso de Wuhan estimavam.

7 O SARS-CoV-2 já aporta em outros países como um vírus conhecido. Assim como outros agentes patógenos que circulam entre nós, ele aparece como mais um daqueles muitos cujas doenças temos e teremos de lidar. E foi lidando com elas que a biomedicina se desenvolveu. No caso brasileiro: a dengue, o sarampo, a cólera, a meningite, a gripe, a poliomielite, a doença de Chagas, etc. Cada uma delas nos remete a uma epidemia diferente que foi diversamente abordada. Essas doenças, apesar de origens patogênicas diversas, remetem a outras doenças com as quais temos de lidar há muito tempo e são produzidas e transmitidas internamente às populações das sociedades humanas. ${ }^{8} \mathrm{~A}$ SARS-CoV-2, apesar de dizerem que veio da China, que foi importada de lá (e ter, com isso, chegado até nós como mais um daqueles seus produtos), já é reproduzida internamente (possui transmissão comunitária), não precisando mais de qualquer 
importação. Isso se não levarmos em conta o fato de que o vírus fora trazido para o Brasil através de pessoas vindas de países europeus 9 . O SARS-CoV-2, portanto, é um vírus que exige o desenvolvimento da ciência brasileira como um todo, mas, apesar disso, o vírus não deixa de ser algo já conhecido em muitos aspectos, como a circulação em humanos e suas patogêneses.

Um outro problema que temos ao tratar do coronavírus é quando precisamos argumentar contra posições que naturalizam o seu surgimento. Os vírus, tomados genericamente, assim como outros agentes patógenos, fazem parte da natureza. Surgiram antes da espécie humana e muito possivelmente continuarão existindo apesar do fim dela. A ciência nos mostra que nem todos os vírus possuem um significado negativo para nós, dado que somente alguns são patogênicos. Porém, antes de conhecermos o significado de um vírus, encontramos doenças de causas desconhecidas. $\mathrm{O}$ acúmulo de conhecimento sobre os diversos patógenos se deu sob muita luta. Antes mesmo dessas doenças, seus agentes patogênicos chegaram até nós por termos antes chegados até eles. No caso do SARS-CoV-2, discute-se qual exatamente foi sua origem. Sabe-se que a origem foi silvestre, mas não se sabe de qual animal ele surgiu.

Quando imaginamos que um animal silvestre é o vetor original de um vírus que contamina humanos, acabamos crendo que o culpado por essa moléstia seria ele. Para isso, poderíamos antes imaginar uma situação originária, onde não se soubesse de doenças transmitidas por animais (ou seja, que nenhum ser vivo, dito de modo mais geral, poderia ser nocivo para nós), e que estes vieram a nos contaminar. Claro que a própria imagem é exagerada. Na prática atual conhecemos que muitas doenças podem ser adquiridas a partir do contato, principalmente prolongado, com outras espécies e, por isso, que eles não chegam até nós sem antes chegarmos até eles, especialmente no nível industrial no qual nos encontramos. Isso implica que o que antes poderia parecer ter uma origem natural, isto é, o vírus por natureza causa doenças em humanos, já é sim um fato social, pois o vírus por meio da sociedade causa doenças em humanos.

Isso seria trivial de ser dito se o processo de manifestação social do significado do SARSCoV-2, vírus em causa, não fosse mais complexo que isso. A sua manifestação pode começar no laboratório, pois este é um momento importante, apesar de pequeno, mas sua manifestação se torna completa, por um lado, quando ele atravessa toda a sociedade (o que é completamente diferente de dizer que ele atravessou toda a população dela) e passa a ser reconhecido como aquilo que ele sempre foi, ou seja, parte dela, e, por outro lado, quando a negatividade de sua manifestação coloca a sociedade em contato com ela mesma nesse processo e dissolve certas relações estabelecidas para formar outras. É aí que o vírus torna-se completamente aquilo que ele sempre foi: nosso.

11 Como Mike Davis expõe no livro "The Monster at Our Door: The Global Threat of Avian Flu" (DAVIS, 2005), os choques ambientais induzidos pela ação humana, como a destruição de pântanos, atividades ligadas ao turismo, megafavelas no "terceiro mundo" etc., são os principais responsáveis pelas epidemias - pelo menos aquelas do começo do século XXI - ao mesmo tempo em que são moldadas pela concentração da pobreza urbana, o negligenciamento da indústria farmacêutica e o colapso dos sistemas de saúde. Ainda conforme o autor, as favelas precisam ser pensadas como enormes epicentros das epidemias, que podem inclusive mudar sua virulência e patogênese. Nesse sentido afirmamos que a pandemia é, em si, um fenômeno urbano que precisa ser 
estudado no contexto brasileiro justamente por conta da peculiaridade de nossa geografia.

Uma história que sempre nos contam na escola é que os portugueses, ao chegarem em terras brasileiras, além de trazerem consigo as benesses da civilização, trouxeram também diversas doenças. Isso não significa que o nosso povo originário estava atrasado quanto às doenças europeias, mas que ambos os povos encontraram-se suficientemente isolados um dos outros para, assim, ao produzirem os seus meios de vida diferentes, encontrarem doenças diversas. Esse momento da história da humanidade é marcado por um relativo isolamento de várias sociedades humanas, o que torna esse acontecimento plausível: os europeus trouxeram consigo as mazelas da civilização para os nossos povos originários. Com o desenvolvimento do capitalismo, do qual a colonização europeia é parte importante, com a sua globalização, esse tipo de isolamento já não é mais possível. Nesse caso dos nossos povos originários e dos povos europeus, o isolamento era relativo, pois compartilhavam uma origem comum, já no nosso caso atual o isolamento já não é mais possível a partir dessa mesma chave. A globalização do capitalismo coloca uma relação necessária entre as diversas sociedades nacionais. E junto a isso, por um lado, a fronteira de expansão capitalista sobre a natureza tem nos colocado cada vez mais em contato com ambientes aparentemente novos (pois já existe um conhecimento científico suficiente sobre as consequências desses novos avanços), fazendo com que novas doenças possam surgir ${ }^{10}$. Por outro lado, o acúmulo de capital veio acompanhado do acúmulo da força de trabalho (e de consumidores) em um mesmo local (em um primeiro momento, para disposição da indústria; em um segundo momento, para dispô-las nas empresas de serviço, e, de modo geral, para a disposição do comércio), fazendo com que as cidades adquirissem a dimensão de metrópoles. Parte fundamental desse mercado global instaurado pelo capitalismo tardio é a rede como forma de organização dos territórios. Mercadorias, sejam celulares, força de trabalho, respiradores ou livros, são trocadas pelo mundo e há uma necessidade desse processo. O SARS-CoV-2 não é um vírus que se desenvolveu visando essa lógica (pois vírus não evoluem intencionando nada), apesar de se valer dela. Como muitos portadores são assintomáticos (e, dentre os sintomáticos, as manifestações levam dias para ocorrer, além do fato de a transmissão acontecer via gotículas d'água expelidas no ar pelo portador do vírus, ou por meio do muco contaminado que pode vir a se fixar em objetos), o vírus consegue se espalhar com muita facilidade sem ser notado ${ }^{11}$. A dinâmica de transmissão do vírus se vale muito do comportamento humano, e na medida em que há uma intensa circulação de pessoas pelo globo, o vírus é capaz de também circular pelo globo. o coronavírus revela essa lógica de circulação de pessoas típica do capitalismo globalizado.

\section{2) Vulnerabilidade: população de risco ou população de inválidos para o trabalho?}

13 Uma das características da doença transmitida pelo coronavírus é que ela atinge mais severamente idosos ou enfermos, população com a maior taxa de mortalidade em decorrência dessa doença. Podemos argumentar que, como pessoas mais velhas e enfermas possuem, pela sua condição clínica, um sistema imunológico mais frágil, é natural que vitime mais essa população que outras. Em que pese isso que nos é apresentado, podemos levar em consideração alguns fatores. Primeiro, sabemos que se uma pessoa tem um corpo debilitado, mora ou vive em condições não adequadas à saúde ou convive com quem não tenha acesso à saúde adequada, ela então poderá, 
eventualmente, ficar doente. Então, se há pessoas com saúde fragilizada hoje, há de se olhar àquilo que a sociedade faltou a essas pessoas, fragilizando a saúde delas. Há uma dívida da sociedade para com essas pessoas enfermas. Outra dívida é com os milhões de pessoas que vivem em condições insalubres, o que é uma realidade no Brasil. Além disso, a concentração e a aglomeração de gente para todos os lados nas metrópoles tornam vulneráveis todos aqueles que vivem nela. Em cima disso, há um problema bastante generalizado no acesso à saúde, não somente relativo à educação sanitária, como também aos diagnósticos pelos especialistas. Como o desenvolvimento da medicina e da farmacologia está atrelado à lógica do desenvolvimento econômico, a mesma lógica que obriga as pessoas viverem aglomeradas nas metrópoles, há uma tragédia em curso.

Ao mesmo tempo em que as ciências médicas e farmacológicas estão avançando, a difusão dos seus resultados pela sociedade, principalmente no neoliberalismo, tem sido feita por meio do mercado, seja pela venda direta da medicina e da farmacologia aos pacientes transformados em clientes ${ }^{12}$, seja com o Estado pautando a questão da saúde como apenas um gasto, um investimento, e não como a garantia de um direito fundamental ${ }^{13}$, algo sem o qual não há as mínimas condições materiais de realização da vida em sociedade. $O$ sistema de saúde atual tem a expectativa, dado seu inerente cálculo econômico, de não atender a todos. A austeridade - com o seu desatino -, ao querer apertar o cinto na altura da barriga, fazendo os trabalhadores morrerem de fome, apertou, sadicamente, na altura do pescoço, fazendo-os morrerem sem ar.

o caso dos idosos resume toda a problemática. As pessoas idosas são aquelas que possuem o passado da sociedade marcado em seu corpo. Aqueles que tiveram acesso à saúde e trabalharam em condições salubres, sem desgastar-se, possuem não somente uma expectativa de vida maior, mas uma saúde geralmente maior. Em que pese esse fato, os idosos não são vistos como trabalhadores servíveis à sociedade brasileira. Isso fica perversamente atestado quando recentemente aumentaram a idade mínima para se aposentar. Idosos que vivem muito trazem gastos para a previdência e para a saúde. Por serem vistos como algo já gasto, e por acumularem essa falta de cuidado por parte da nossa sociedade, foram colocados na linha de frente da população que mais sofrerá com essa doença. Os enfermos e os idosos vão morrer mais por não compensarem economicamente ${ }^{14}$.

O isolamento social é visto como uma solução importante para esse período pandêmico do coronavírus. Ele deveria ser parte dos direitos à saúde. Porém, quando olhamos para as nossas cidades, vemos esse direito violentado. Algumas partes das cidades dispõem de áreas verdes, terrenos grandes, esgoto canalizado, vias pavimentadas e arborizadas, calçadas cuidadas, parques públicos etc. Essas condicionantes permitem morar em um lugar melhor climatizado, com menor incidência de doenças respiratórias, onde há atividades ao ar livre, saneamento básico adequado, evitando uma série de doenças. Essas condições combinadas são restritas aos bairros mais abastados, que são em extensão menores que os bairros mais pauperizados, onde mora a maior parte da população urbana. É desastrosa a situação sanitária na qual muitos brasileiros foram postos. Não somente pela falta que já vinham enfrentando, mas o resultado possível disso no curso da pandemia. A organização das pessoas doentes, que é algo necessário na contenção da transmissão do vírus, fica inviabilizada pois não há espaços vazios para serem ocupados por aqueles que estão doentes ou na prevenção da transmissão da 
doença. A vulnerabilidade ao vírus, e consequentemente, a sua doença, torna-se algo marcado geograficamente.

17 As reformas trabalhistas e previdenciárias realizadas desde o começo do século XXI no Brasil impuseram à classe trabalhadora brasileira a condição de um emprego muito instável e informal, sem perspectiva de futuro, obrigada a adaptar-se constantemente aos mandos e desmandos da classe dominante, e por um período de tempo antes da aposentadoria também mais longo. Alia-se a isso a precarização dos serviços públicos e das garantias de direitos fundamentais (como à moradia, educação, alimentação e saúde, por exemplo), o que torna necessário, sob a égide do neoliberalismo, a salvação individual de cada um apesar da sociedade. Porém, como sabemos, essa condição de individualização máxima dos problemas dos indivíduos é uma condição social. Há um longo percurso histórico até esse estado lamentável de coisas em que uma parte significativa da população economicamente ativa (cerca de $40 \%$ dela) necessita continuar trabalhando. E o uso do gerúndio aqui não é trivial, pois é justamente essa a condição lamentável: para continuar sobrevivendo, há a necessidade constante da realização de algum tipo de trabalho que dele provenha alguma renda. A frase de um ex-presidente brasileiro - "Não fale em crise, trabalhe"15 - sintetiza o nível de expropriação: aquilo que mais atinge a classe trabalhadora não pode ser posto em questão, é um tabu, pois trabalhar é a única saída dada ao indivíduo. A crise é uma maldição lançada sobre os trabalhadores.

Outros dois fatos são importantes. 0 primeiro é que a metrópole concentra mão-deobra, mas não a organiza de modo que o trabalhador esteja próximo ao seu(s) local(is) de trabalho. $O$ segundo é que a flexibilização das relações de trabalho acompanha uma flexibilização maior das relações de produção com o modo de organização produtiva just-in-time. Apesar de costumeiramente traduzirmos essa expressão inglesa para o português como "na hora certa", "just" para a classe trabalhadora além do sentido de "certo" também significa "justo" (de apertado) e "injusto" (de ausência de direitos, dado que a justiça somente chegaria na hora certa). o coronavírus ilumina isso ao tornar até o isolamento social, única salvação por ora, uma forma de violência contra essas pessoas, e violência esta que é usada por parte da classe dominante para jogar, para fora do isolamento social, essas pessoas para a morte ${ }^{16}$.

\section{3) Preparação: serviços públicos aos trancos e barrancos}

19 A questão da preparação é ampla e extremamente contraditória. Envolve tanto o acúmulo de conhecimento científico que ajudaria no conhecimento prévio dos processos naturais que podem levar ao desastre social quanto o modo como nos preparamos socialmente para evitar tal desastre diante das vulnerabilidades presentes na sociedade. Contudo, a sociedade capitalista, como sempre, aparece como um empecilho. Afinal, precisamos sempre lembrar que as relações de produção impedem o pleno desenvolvimento das forças produtivas. Pensemos, por exemplo, que o coronavírus é discutido pela literatura médica especializada desde a década de 1960, mas os impeditivos para o desenvolvimento e distribuição de vacinas são fundamentalmente econômicos. Conforme Mike Davis expõe, a produção privada de vacinas apresenta contradições internas, pois são caras e não têm o retorno desejado, já que sua demanda é sazonal. Ainda segundo Davis, a produção e distribuição de vacinas feitas em Cuba é infinitamente melhor que a estadunidense por não responder a interesses mercadológicos. Assim como não há desastres naturais em Cuba, também 
não há uma saúde mercantilizada. Como bem disse o presidente francês, Emmanuel Macron, "a saúde gratuita e nosso Estado-providência não são gastos e encargos, mas bem preciosos. [...] o que revela esta pandemia é que há bens e serviços que devem ser colocados fora das leis do mercado." ${ }^{17}$ Não precisamos enfatizar o quanto Macron é expoente do neoliberalismo. Sua fala, contudo, é sintomática das contradições expressas pela pandemia. Por um lado, a necessidade de solidariedade como estratégia de superação desse trágico momento. Por outro, os interesses materiais específicos que impedem qualquer ação minimamente necessária.

E no caso brasileiro, com o Sistema Único de Saúde (SUS) e todas as instituições públicas de ciência, não deveríamos estar minimamente preparados para eventuais desastres? Não precisamos, neste breve ensaio, aprofundar a discussão sobre a precarização e os constantes ataques que essas instituições vêm sofrendo nos últimos anos - precisaríamos de páginas e mais páginas apenas para elencar os absurdos e constantes ataques às universidades públicas. Fica nítido, portanto, o ódio dos últimos governos federais - principalmente após o golpe de Estado em 2016 - pela coisa pública e, consequentemente, com a classe trabalhadora. Cinicamente atacam aquilo que seria o principal na contenção da pandemia enquanto tentam naturalizar o desastre. Temos, assim, um SUS, público e universal, incapaz de se preparar adequadamente ao desastre porque é preciso mostrar na prática que as instituições públicas não funcionam, mesmo que isso custe a vida de milhares. Aliás, podemos falar que essas mortes são políticas de Estado: são o modo como o Estado brasileiro poderá aliviar os gastos públicos, porque é fundamental transferir capital para as empresas privadas poderem sobreviver a essa crise - o Brasil não pode parar e a economia é mais importante do que salvar vidas. Afinal, o que são cinco ou sete mil mortes diante do colapso da economia? ${ }^{18}$

\section{4) Resultados e Resposta: alívio dos sistemas públicos de saúde e previdenciário}

21 Como escrevemos este texto antes do pico de casos de COVID-19 no Brasil, há uma certa dificuldade na determinação concreta dos resultados desse desastre social em curso, ainda mais as respostas diante desses resultados. Porém, como já viemos argumentando, para a classe dominante há uma expectativa de alívio do sistema previdenciário, uma saída do sistema solidário, para um outro no qual cada um invista na sua própria aposentadoria por meio de um banco (e confie na solvência desse banco daqui algumas décadas). A morte de idosos desonera aqueles que pagam sua aposentadoria por meio do modelo solidário de previdência, quebrando a solidariedade entre as gerações existentes nesse modelo. A morte dos trabalhadores que estão inseridos nesse modelo o tensiona, empurrando a necessidade da adoção futura de um modelo neoliberal de previdência. Alívio também para o sistema público de saúde, que não precisará lidar com muitos enfermos já sabidos e muitos enfermos ainda não diagnosticados. Empurrar o modelo privado de saúde, apesar de a própria realidade do vírus apontar seu fracasso retumbante, será facilitado. Um aspecto importante é que, na capital do estado de São Paulo, epicentro do coronavírus no Brasil, a estrutura que está sendo erguida para a contenção do coronavírus, até onde pode-se perceber, não aponta para a edificação de estruturas perenes, acumulando avanço para o sistema público de saúde. Pelo contrário, há a edificação de estruturas temporárias, com hospitais just-in-time de campanha, realocação de recursos, compras de equipamentos em mercados exteriores, etc., mesmo com o conhecimento de que a pandemia poderá 
durar meses (e ter mais de um ciclo de surto). A morte vai facilitar esses retrocessos para a classe trabalhadora, e por isso ela pode ser benéfica para seus algozes.

A pandemia traz consigo um debate econômico - porém, o que não é fundamentalmente econômico na sociedade capitalista? o debate oscila entre aqueles que pretendem justificar a crise do capitalismo como consequência direta do fechamento dos mercados por causa do vírus, e aqueles aparentemente preocupados apenas com a reconstrução após a pandemia. De um lado, aqueles que tomam a pandemia como bode expiatório para as quedas nas bolsas ao redor do mundo, a falta de liquidez, os circuit-breakers, as quedas das taxas de lucro, a fuga de capitais e, assim, legitimar a socialização dos prejuízos como foi com a crise dos subprimes em 2008. De outro, a aparente preocupação dos especialistas que pretendem reconfigurar a luta intraclasse da classe dominante com o mundo pós-pandemia, e, para tanto, clamam por uma virada keynesiana que garantirá a circulação de capital. A constante que liga esses dois pólos do debate é o ataque aos trabalhadores como estratégia de sobrevivência: são eles quem pagarão pela manutenção do modo de produção capitalista e dos privilégios dessa classe patogênica, seja com seus direitos e ativos duramente conquistados, seja com as vidas perdidas durante a pandemia.

Em primeiro lugar precisamos afirmar que a pandemia não pode ser usada como justificativa, como uma causa exógena de uma nova crise do capitalismo. Ao contrário, afirmamos que a crise não é atual, mas estrutural (MÉSZÁROS, 2011) e cíclica (HARVEY, 2015), e os desdobramentos da pandemia poderão levar a um aprofundamento das contradições de uma economia que já vinha se mostrando extremamente fragilizada desde a crise dos subprimes de 2008 (cf. ROBERTS, 2020a, 2020b, 2020c, 2020d). A pandemia, portanto, é um fator novo que precisa ser discutido no que diz respeito ao modo como as cadeias produtivas estão sendo afetadas (cf. HARVEY, 2020). Todavia, não é esse nosso intuito. Pretendemos, aqui, apenas discutir algumas contradições levantadas pelo debate economicista que ronda as soluções mágicas da pandemia. No momento atual em que escrevemos ainda não há uma solução final para a economia. Logo, apenas a luta de classes definirá os caminhos que percorreremos daqui em diante.

Apesar de não termos chegado no Brasil ao ápice da curva de contaminação pelo vírus, quando se espera ser a maior quantidade de pessoas contaminadas ao mesmo tempo (o chamado pico do surto), pode-se ver as respostas do Estado brasileiro diante do problema em curso. Uma delas, que é bastante trágica e sintética, e dividiu os mais diferentes poderes executivos dos diversos níveis administrativos, é o debate sobre o que salvar: os lucros ou as vidas. Tragicômica para a classe dominante, salvar todas as vidas ou salvar a si mesma, essa decisão não é nenhuma novidade. No presente contexto, o que não parecia imediato para muitos antes do coronavírus, pode se tornar imediato: a classe dominante não vê nada nas vidas senão possibilidade de lucro, seja presente, seja futuro. É importante frisar que a imediaticidade desse fenômeno não é tão evidente quanto pode nos parecer agora. Como é por meio da economia que a classe trabalhadora obtém suas condições materiais para a reprodução da sua força de trabalho, ou seja, seus meios de vida enquanto trabalhador, e, por meio da exploração dessa força de trabalho a classe dominante extrai mais valor da classe trabalhadora, obtendo, por fim, lucro, a resposta que a classe dominante, por meio do Estado, dá diante da pandemia é a colocação desse dilema real: salvar a economia (agora) ou salvar a economia (depois). A economia representa o lucro da classe dominante ao mesmo tempo que é, de fato, o meio de vida da classe trabalhadora. A parte da classe 
dominante que, na sanha de defender seus lucros agora, relega a vida imediata da classe trabalhadora para depois, de fato revela o projeto genocida presente no seio de toda classe dominante, o que vem sendo exposto até agora. Nessa defesa suicida do lucro há, contudo, uma afirmação importante e fundamental, que está acima daquela do dilema real da classe dominante: a classe trabalhadora é fundamental para a vida da classe dominante, enquanto o contrário não é verdadeiro.

o que se pode esperar como resultado, ainda que um pouco abstrato, possui determinantes bem concretas, como estamos vendo até aqui. Se todo o processo que nos trouxe a essa presente catástrofe permanecer em sua autonomização, como se a história do Brasil fosse apenas mais uma força da natureza, como querem que vejamos o vírus, então pode-se esperar a instauração, como resposta definitiva, de uma situação de morte. $O$ toque da morte que o coronavírus parece possuir é apenas o toque dessa nossa sociedade suicida, onde o Estado possui um papel importante na desarticulação de soluções que afirmam a vida. A aparente confusão instaurada no âmbito federativo, e na própria federação como um todo, com o conflito de propostas entre prefeitos municipais, governadores estaduais e a presidência da república, como uma resposta à chegada do vírus, não pode ser vista apenas como conflito de interesses, mas como um conflito constituinte do Estado federativo brasileiro. 0 coronavírus somente revela esse truque de ilusionismo que embalou os sonhos de muitos brasileiros.

\section{5) Reconstrução: planificação estatal subsumida ao Capital}

Algumas avaliações devem ser feitas para o que se pode esperar, além do já dito, para o pós-pandemia no Brasil. A pandemia, e a expectativa de uma pandemia ainda pior no futuro, coloca a necessidade de se organizar as diversas sociedades do mundo para esse próximo momento. A organização desse sistema não implica, necessariamente, uma organização harmônica. O Brasil é um exemplo muito bom de como se organiza um conflito conservando-o em seu interior. Aqui, o discurso estatal sobre o coronavírus já deixa evidente o modo de abordagem a ele: a guerra. Como pudemos ver até aqui, não é necessário enfrentar essa pandemia como uma guerra, pois o problema do coronavírus está dentro da sociedade brasileira e não fora dela. 0 discurso bélico serve para, por um lado, suspender os conflitos de classe efervescentes no país (mas sem suspender as mortes advindas deles), e, por outro lado, unido àquele, para pautar a solidariedade, algo fundamental para esse processo, como uma solidariedade de cunho nacionalista, sem fundamento político constituído pela classe trabalhadora brasileira. Defender o país simplesmente é defender toda essa negatividade que ele produz, todas essas mortes que ele intencionalmente causa. Por isso, a organização porvir da sociedade brasileira pode muito bem vir a passar por aquilo que ela mais sabe fazer: mediar as relações sociais pelo emprego das forças policiais, fundamentalmente as militares. Essa militarização das relações sociais (que significa dizer militarização dos conflitos sociais) vai fazer com que as forças policiais estaduais e, consequentemente, o papel dos estados, sejam ainda mais relevantes.

A federação, que já se encontrava precarizada, dado o nível dramático do conflito de classes e conflitos inter-regionais, dado o histórico de desenvolvimento geográfico desigual das regiões intra-nacionais, pode ser resumida na constituição dos Consórcios Sul-Sudeste (também chamado de COSUD) e Nordeste em 2019. A regionalização histórica do país, que tem nessas duas regiões um antagonismo importante, foi evidenciada com as eleições de 2018, onde a maior parte dos governadores 
progressistas foram eleitos na região Nordeste, e os governadores alinhados ao neoliberalismo foram eleitos nas regiões Sul-Sudeste. Isso facilitou a instituição desses consórcios nessas regiões, que estão sendo fundamentais para o chamado "combate ao coronavírus", para a lida com a pandemia. Com a cereja do bolo sendo a posição da presidência da república, nitidamente contrária a qualquer medida de contenção da pandemia que tenha como resultado o salvamento de vidas. Isso mostra como já vinha sendo acumulado há anos um desgaste na figura da presidência dada a dificuldade de estabelecimento da federação. Com os governos estaduais lidando individualmente com a pandemia, mesmo que coletivizando essa lida com outros estados e regiões, e com a fratura crescente da federação (OLIVEIRA, 1993), há uma tendência para um acúmulo futuro, ainda mais no enfrentamento de uma pandemia futura, de poderes nas mãos dos estados.

Todos esses movimentos anteriores culminam na planificação da economia. Parece se impor, com esta pandemia, uma necessidade de planejamento mais estruturado para uma crise econômica a surgir com uma próxima pandemia. Isso demandará do Estado um poder muito maior e mais imediato de intervenção na sociedade para que ela evite a sua própria ruína. Na China, por exemplo, a possibilidade de intervenção rápida da sociedade pelo Estado fez com que o coronavírus não somente fosse conhecido, como fosse contido. Nos EUA, por outro lado, a privatização difusa dos meios de vida da sociedade fez com que o pólo mundial da economia do vírus migrasse rapidamente da China para os EUA. A tendência neoliberal que vem se instalando no Brasil, que encontra essa necessidade de planificação econômica imposta pela crise atual do capitalismo evidenciada pela pandemia, parece nos levar para uma necessária planificação privada da economia a ser realizada pelo Estado. Esse Frankenstein, se seguir as tendências de terceirização das partes e funções do Estado como vem ocorrendo, será de um Estado com cada vez mais poderes de intervenção imediata na sociedade, intervenção imediata mediada necessariamente por empresas privadas ${ }^{19}$. Empresas privadas que, na lógica de capitalismo dependente aprofundada pelo governo atual, são estrangeiras ou estão atreladas a interesses estrangeiros. Há, portanto, uma tendência aparente do fortalecimento das relações em escala local que, de fato, serão o fortalecimento das relações em escala global.

\section{Conclusão}

Walter Benjamin (1892-1940), em seu último texto - "Sobre o conceito da história" alerta-nos que a ascensão do fascismo não deveria ser vista com espanto, mas como expressão da barbárie que é a regra da própria luta de classes, como um estado de exceção permanente ${ }^{20}$. Para o filósofo, esse espanto se deve a doutrina cega da ilusão do progresso da história, cuja norma deveria ser melhorias na liberdade, na democracia, nas ciências, nas técnicas. O fascismo, contudo, crescia alinhado com esse progresso e com a sociedade industrial. Seria preciso, portanto, uma concepção de história verdadeiramente alinhada com os oprimidos, que fornecesse os meios através dos quais a luta pela emancipação fosse possível, ou seja, capaz de enfrentar a catástrofe iminente do fascismo: contra esse estado de exceção permanente, criar as condições para se abolir a dominação e a sociedade de classes através de revoltas e sublevações que interrompam o cortejo triunfante dos dominantes, o prosseguimento da marcha fúnebre. 
A pandemia é a expressão máxima do acúmulo de contradições do modelo neoliberal. É um estado de exceção no qual se coloca diante dos trabalhadores uma escolha: morrer trabalhando ou trabalhar até morrer, mesmo que para isso seja necessário a decretação de um estado de sítio $^{21}$. O trabalho alienado não liberta, é uma impossibilidade em termos. Faz-se necessário, contudo, a concepção de uma teoria crítica que marque nossa posição na luta contra os ataques vindouros da classe dominante. "Capitalism über alles” (SMITH, 2010, p. 51) é a frase sintética com que Neil Smith resume a forma pela qual a esquerda foi tomada de assalto e capturada pela ideologia neoliberal. Contrário às propostas keynesianas introduzidas após a crise dos subprimes de 2008 um New New Deal, como chamou na época (SMITH, 2010, p. 61) -, o autor preconizava a revolução como a saída possível que deveria ser levantada pela esquerda - novamente. Diante da pandemia e do aprofundamento da crise capitalista, a solidariedade é uma bandeira vaga levantada como estratégia para uma possível superação do momento. Porém, é imprescindível perguntar-nos, antes, de qual solidariedade falamos: da bandeira nacionalista do Brasil acima de tudo que enterrará a tudo e a todos ou da solidariedade entre a classe trabalhadora que fornecerá a base capaz de sobrepujar a barbárie da ideologia neoliberal? Optamos, sempre, pela solidariedade revolucionária.

\section{BIBLIOGRAFIA}

BENJAMIN, Walter. Magia e técnica, arte e política: ensaios sobre literatura e história da cultura. São Paulo: Brasiliense, 2012.

DAVIS, Mike et al. Coronavírus e a luta de classes. Brasil: Terra Sem Amos, 2020.

Planeta favela. São Paulo: Boitempo, 2018.

The Monster at Our Door: The Global Threat of Avian Flu. Nova Iorque: The New Press, 2005.

HARVEY, David. O enigma do capital e as crises do capitalismo. São Paulo: Boitempo, 2014.

. Os Limites do Capital. São Paulo: Boitempo, 2015.

. Condição Pós-moderna: uma pesquisa sobre as origens da mudança cultural. 22. ed. São

Paulo, Loyola, 2012.

LÖWY, Michael. A revolução é o freio de emergência: ensaios sobre Walter Benjamin. São Paulo: Autonomia Literária, 2019.

. Walter Benjamin: aviso de incêndio: Uma leitura das teses "Sobre o conceito de história". São Paulo: Boitempo, 2014.

MARX, Karl. Grundrisse: Manuscritos econômicos de 1857-1858: esboços da crítica da economia política. São Paulo: Boitempo, 2016.

. Manuscritos econômico-filosóficos. São Paulo: Boitempo, 2010.

. O Capital: crítica da economia política: Livro I: o processo de produção do capital. São

Paulo: Boitempo, 2015. 
MARX, Karl \& ENGELS, Friedrich. A ideologia alemã. São Paulo: Boitempo, 2016.

MÉSZÁROS, István. A crise estrutural do capital. São Paulo: Boitempo, 2011.

OLIVEIRA, Francisco de. A questão regional: a hegemonia inacabada. Estudos Avançados (USP), 7, n. 18 , pp. 43-63, 1993.

ROBERTS, Michael. A war economy?. Disponível em <https://thenextrecession.wordpress.com/ 2020/03/30/a-war-economy/> . Acesso em: 06 de abril de 2020a.

. Disease, debt and depression. Disponível em <https://thenextrecession.wordpress.com/ 2020/03/05/disease-debt-and-depression/>. Acesso em: 06 de abril de 2020 b.

. It was the virus that did it. Disponível em $<\mathrm{https}$ ://thenextrecession.wordpress.com/ 2020/03/15/it-was-the-virus-that-did-it/>. Acesso em: 06 de abril de 2020c.

The "emerging market" slump. Disponível em <https://thenextrecession.wordpress.com/ 2020/03/19/the-emerging-market-slump/>. Acesso em: 06 de abril de $2020 \mathrm{~d}$.

SAFATLE, Vladimir. Bem vindo ao Estado suicidário. Pandemia Crítica. São Paulo: N-1 Edições, 2020.

SMITH, Neil. Nature as Accumulation Strategy. Socialist Register, 43, pp. 16-36, 2006.

. The Production of Nature. In.: ROBERTSON, George et al. (org.). FutureNatural: nature, science, culture. Londres: Routledge, 1996.

. The Revolutionary Imperative. Antipode, 41, pp. 50-65, 2010.

. The Satanic Geographies of Globalization: Uneven Development in the 1990s. Public Culture, 10 (1), pp. 169-189, 1997.

. "There's No Such Thing as a Natural Disaster". Disponível em: <https://items.ssrc.org/ understanding-katrina/theres-no-such-thing-as-a-natural-disaster/>. Acesso em: 06 abr. 2020.

. Uneven development: nature, capital, and the production of space. Georgia: The University of Georgia Press, 2008.

\section{NOTAS}

1. "WHO Director-General's opening remarks at the media briefing on COVID-19 - 11 March 2020" ["Anúncio de abertura do Diretor-Geral da OMS na coletiva de imprensa sobre o COVID-19 - 11 mar. 2020"] Disponível em: <https://www.who.int/dg/speeches/detail/who-director-general-sopening-remarks-at-the-media-briefing-on-covid-19---11-march-2020>. Publicado em: 11 mar. 2020. Acesso em: 06 abr. 2020.

2. "Trump sparks anger by calling coronavirus the 'Chinese virus'" ["Trump provoca raiva ao chamar coronavírus de 'vírus chinês"'] Disponível em: <https://www.theguardian.com/world/ 2020/mar/17/trump-calls-covid-19-the-chinese-virus-as-rift-with-coronavirus-beijingescalates>. Publicado em: 17 mar. 2020. Acesso em: 06 abr. 2020.

3. “'Gripezinha': leia a íntegra do pronunciamento de Bolsonaro sobre covid-19” Disponível em: $<$ https://noticias.uol.com.br/politica/ultimas-noticias/2020/03/24/leia-o-pronunciamento-dopresidente-jair-bolsonaro-na-integra.htm>. Publicado em: 24 mar. 2020. Acesso em: 06 abr. 2020. 4. "As world struggles to stop deaths, far right celebrates COVID-19" ["Enquanto o mundo luta para parar as mortes, a extrema-direita celebra a COVID-19"] Disponível em: <https:// www.aljazeera.com/indepth/features/world-struggles-stop-deaths-celebratescovid-19-200326165545387.html>. Publicado em: 26 mar. 2020. Acesso em: 06 abr. 2020. 
5. "Pesquisas mostram economia global devastada por pandemia de coronavírus" Disponível em: $<$ https://exame.abril.com.br/economia/pesquisas-mostram-economia-global-devastada-porpandemia-de-coronavirus/>. Publicado em: 25 mar. 2020. Acesso em: 06 abr. 2020. "Novo coronavírus reduz renda de metade dos brasileiros, diz pesquisa" Disponível em: <https:// economia.estadao.com.br/noticias/geral,novo-coronavirus-reduz-renda-de-metade-dosbrasileiros-diz-pesquisa,70003267990>. Publicado em: 12 abr. 2020. Acesso em: 12 abr. 2020.

6. Ou algo que pode ser aproximado disso, seja lá o que isso signifique. Como o argumento de que, por conta do decreto federal de calamidade pública, poderia se argumentar a possibilidade de saque do Fundo de Garantia por Tempo de Serviço (FGTS) pelo fato de que a pandemia se aproxima de um desastre natural, conforme este argumento do jurista Marco Aurélio Serrau Júnior. "Medida Provisória 927 - Alterações trabalhistas em tempos de coronavírus \# 3 - Como fica o FGTS?" Disponível em: <http://genjuridico.com.br/2020/04/01/mp-927-como-fica-o-fgts/>. Acesso em: 06 abr. 2020.

7. Título que pode ser traduzido como "Desastres naturais não existem".

8. Mas isso não se reduz somente ao Brasil. No ano do centenário da Gripe de 1918, que vitimou 50 milhões de pessoas (estimativas), o Diretor-Geral da Organização Mundial da Saúde, Dr. Tedros Adhanom Ghebreyesus, apontou a expectativa de uma nova pandemia e a necessidade da tomada de ações preventivas. "Can we create a pandemic-free world?" ["Podemos criar um mundo sem pandemias?"] Disponível em: <https://www.who.int/dg/speeches/2018/pandemic-free-world/ en/>. Publicado em: 12 fev. 2018. Acesso em: 06 abr. 2020.

9. A imensa maioria dos casos iniciais, cujos vírus tiveram seu genoma sequenciado, indicam que eles vieram da Europa e não da Ásia (17 contra 2 dos 19 genomas sequenciados até março). Sobre os primeiros dois casos identificados no Brasil: "Genoma do $2^{\circ}$ caso de coronavírus do Brasil é diferente do $1^{\circ}$, apontam cientistas brasileiros" Disponível em: <https://saude.estadao.com.br/ noticias/geral,genoma-do-2-caso-de-coronavirus-do-brasil-e-diferente-do-1-apontam-cientistasbrasileiros,70003217291>. Publicado em: 02 mar. 2020. Acesso em: 09 abr. 2020. Sobre os 19 casos citados: "Transmissão comunitária: Genoma mostra que o novo coronavírus adquiriu características singulares no Brasil” Disponível em: <https://oglobo.globo.com/sociedade/ coronavirus/transmissao-comunitaria-genoma-mostra-que-novo-coronavirus-adquiriu-

caracteristicas-singulares-no-brasil-24328953>. Publicado em: 26 mar. 2020. Acesso em: 09 abr. 2020.

10. Um exemplo local talvez possa ser, mesmo, a Floresta Amazônica: "Cientistas buscam identificar a fonte da próxima pandemia" Disponível em: <https://oglobo.globo.com/sociedade/ saude/cientistas-buscam-identificar-fonte-da-proxima-pandemia-21514700>. Publicado em: 26 jul. 2017. Acesso em: 09 abr. 2020. Em uma escala global, podemos citar o trabalho de pesquisa feito pelo biólogo evolutivo Rob Wallace, que procura estudar a relação entre o desenvolvimento capitalista e o surgimento de epidemias e pandemias. Em uma entrevista sobre o surgimento do novo coronavírus, ele aponta o relacionamento entre o agronegócio com o aparecimento de pandemias. "Capitalist agriculture and Covid-19: a deadly combination" ["Agricultura capitalista e Covid-19: uma combinação mortal"] Disponível em: <https://climateandcapitalism.com/ 2020/03/11/capitalist-agriculture-and-covid-19-a-deadly-combination/>. Publicado em: 11 mar. 2020. Acesso em: 12 abr. 2020.

11. Há pesquisas indicando que o vírus também pode ser transmitido pela respiração, aerossolizado, o que torna a situação ainda mais trágica. "You may be able to spread coronavirus just by breathing, new report finds" ["Você pode ser capaz de espalhar o coronavírus apenas pela respiração, novo relatório aponta"] Disponível em: <https://www.sciencemag.org/news/ 2020/04/you-may-be-able-spread-coronavirus-just-breathing-new-report-finds>. Publicado em: 02 abr. 2020. Acesso em: 12 abr. 2020.

12. Podemos citar o caso da vacina contra o SARS-CoV e a MERS-CoV, outros coronavírus, que foi interrompida por não ser economicamente viável, e seria fundamental agora para a contenção da 
pandemia. "Coronavírus: como o mundo desperdiçou a chance de produzir vacina para conter a pandemia" Disponível em: <https://www.bbc.com/portuguese/internacional-52238530>. Publicado em: 10 abr. 2020. Acesso em: 10 abr; 2020.

13. A chamada "PEC da Morte", como é conhecida na esquerda política, ou "PEC do Teto dos Gastos Públicos", como é divulgada pela imprensa, chamada de "Novo Regime Fiscal" oficialmente, ou Emenda Constitucional 95, instituída em 2016, resume bem essa perspectiva, limitando o orçamento público pelos próximos 20 anos. Disponível em: <http:// www.planalto.gov.br/ccivil_03/constituicao/Emendas/Emc/emc95.htm>. Publicado em: 15 dez. 2016. Acesso em: 12 abr. 2020. Esse desmonte da saúde pública é criticado há muito tempo. Podemos destacar duas matérias publicadas por jornais alinhados à esquerda política. "Desmonte do SUS: ‘A partir de 2018, vamos ter uma volta ao passado"' Disponível em: <https:// www.redebrasilatual.com.br/saude-e-ciencia/2017/03/desmonte-do-sus-a-partir-de-2018vamos-ter-uma-volta-ao-passado/>. Publicado em: 03 mar. 2017. Acesso em: 12 abr. 2020. "Desmonte do SUS deve causar 50 mil mortes precoces no Brasil até 2030, aponta estudo" Disponível em: <https://www.brasildefato.com.br/2019/04/29/desmonte-do-sus-deve-causar-50mil-mortes-precoces-no-brasil-ate-2030-aponta-estudo>. Publicado em: 29 abr. 2019. Acesso em: 12 abr. 2020.

14. Podemos também citar, além dos idosos (e dos enfermos de modo geral), o recorte racial como decisivo na qualificação de parte da sociedade como população vulnerável. "Entre casos identificados, covid-19 se mostra mais mortífera entre negros no Brasil, apontam dados" Disponível em: <https://www1.folha.uol.com.br/cotidiano/2020/04/coronavirus-e-mais-letalentre-negros-no-brasil-apontam-dados-da-saude.shtml>. Publicado em: 10 abr. 2020. Acesso em: 10 abr. 2020. Mas isso não se limita somente ao Brasil. "Virus Is Twice as Deadly for Black and Latino People Than Whites in N.Y.C." ["Vírus é o dobro mais mortal para pretos e latinos que para brancos na cidade de Nova Iorque"] Disponível em: <https://www.nytimes.com/2020/04/08/ nyregion/coronavirus-race-deaths.html>. Publicado em: 08 abr. 2020. Acesso em: 10 abr. 2020.

15. “'Não fale em crise; trabalhe', diz Temer, em seu 1ํㅜ pronunciamento como presidente em exercício" Disponível em: <https://www.huffpostbrasil.com/2016/05/12/nao-fale-em-crisetrabalhe-diz-temer-em-seu-1-pronunciamen_n_9937822.html>. Publicado em: 12 maio 2020. Acesso em: 06 abr. 2020.

16. E isso é o que vem acontecendo. "Do Einstein para o SUS: a rota letal da Covid-19" Disponível em: <https://piaui.folha.uol.com.br/do-einstein-para-o-sus-rota-letal-da-covid-19/>. Publicado em: 10 abr. 2020. Acesso em: 10 abr. 2020.

17. "Contra Trump e nacionalismos, Macron tenta coordenar resposta da UE a coronavírus" Disponível em: <https://oglobo.globo.com/mundo/contra-trump-nacionalismos-macron-tentacoordenar-resposta-da-ue-coronavirus-24304796>. Publicado em: 14 mar. 2020. Acesso em: 06 abr. 2020.

18. “Coronavírus: Empresários minimizam pandemia e são criticados na internet" Disponível em: <https://www.correiobraziliense.com.br/app/noticia/brasil/2020/03/24/interna-brasil,836326/ coronavirus-empresarios-minimizam-pandemia-e-sao-criticados-internet.shtml>. Publicado em: 24 mar 2020. Acesso em: 06 abr. 2020.

19. Sobre a participação das empresas privadas de telecomunicação móvel na produção de dados sobre aglomeração de pessoas para a tomada de ações por parte do governo federal: "Coronavírus: governo brasileiro vai monitorar celulares para conter pandemia" Disponível em: <https://www.terra.com.br/noticias/coronavirus/coronavirus-governo-brasileiro-vaimonitorar-celulares-para-conter-pandemia,62ec110da1579b3ae5eb3971b82966b6koliy3ms.html>. Publicado em: 03 abr. 2020. Acesso em: 06 abr. 2020. Sobre o "Coronavirus Chat" do Ministério da Saúde: "Robô auxilia na triagem online de possíveis casos do novo coronavírus" Disponível em: <https://todahora.com/articulos/rob\%C3\%B4-auxilia-na-triagem-online-de-poss\%C3\%ADveiscasos-do-novo-coronav\%C3\%ADrus>. Publicado em: 18 mar. 2020. Acesso em: 06 abr. 2020. 
20. “A tradição dos oprimidos nos ensina que o 'estado de exceção' [...] em que vivemos é a regra. Precisamos construir um conceito de história que corresponda a essa ensinamento. Perceberemos, assim, que nossa tarefa é originar um verdadeiro estado de exceção; e com isso nossa posição ficará melhor na luta contra o fascismo." (BENJAMIN, 2012, p. 245).

21. "Bolsonaro diz que 'ainda' não considera decretar estado de sítio por coronavírus". Disponível em: <https://www1.folha.uol.com.br/poder/2020/03/bolsonaro-diz-que-ainda-naoconsidera-decretar-estado-de-sitio.shtml>. Publicado em: 20 de março de 2020. Acesso em: 06 de abril de 2020 .

\section{RESUMOS}

A atual pandemia de COVID-19 causada pelo novo coronavírus (SARS-CoV-2) é vista pela sociedade brasileira como a causa dos problemas econômicos, assim como o vírus e seus efeitos são tidos como se fossem externos à sociedade. A partir do método de análise do geógrafo marxista Neil Smith (1954-2012), o objetivo deste texto é criticar tal perspectiva mostrando que o problema surge no âmago da sociedade capitalista.

Provoquée par le nouveau coronavirus (SARS-CoV-2), l'actuelle pandémie de la Covid-19 est comprise par la société brésilienne en tant que la cause des problèmes économiques, ainsi que le virus et ses effets ont prises comme s'ils étaient extérieurs à la société elle-même. A partir des leçons du géographe marxiste Neil Smith (1954-2012), le but de cet article est de s'opposer à cette grille de lecture en soulignant que le problème est né à l'intérieure de la société capitaliste.

La actual pandemia de COVID-19 causada por el nuevo coronavirus (SARS-CoV-2) es vista por la sociedad brasileña como la causa de problemas económicos, así como el virus y sus efectos son considerados externos a la sociedad. Basado en el método de análisis del geógrafo marxista Neil Smith (1954-2012), el objetivo de este texto es criticar esta perspectiva que muestra que el problema surge en el corazón de la sociedad capitalista.

Produced by the new coronavirus SARS-CoV-2, the ongoing COVID-19 pandemic is regarded by the Brazilian Society as the cause of economic crisis, besides the fact that virus and its effects are realized as if they were born from outside society. Based on Neil Smith Marxist geographer, the aim of this paper is to criticise that perspective and show that the origins of the crisis is rooted in the heart of the capitalist society.

\section{ÍNDICE}

Mots-clés: coronavirus au Brésil, désastre naturel, développement inégale, géographie radicale, critique marxiste

Palavras-chave: Coronavírus no Brasil, desastre natural, desenvolvimento desigual, geografia radical, crítica marxista.

Keywords: Coronavirus in Brazil, natural disaster, uneven development, radical geography, Marxist criticism

Palabras claves: Coronavirus en Brasil, desastre natural, desarrollo desigual, geografía radical, crítica marxista. 


\section{AUTORES}

\section{JOÃO ALVES DE SOUZA NETO}

Licenciado em Geografia pelo IFSP (campus São Paulo), Mestrando em Geografia do Programa de Pós-Graduação em Geografia da Universidade Estadual de Campinas, Professor de Geografia da Prefeitura Municipal de São Paulo, Coordenador do Grupo de Estudo Neil Smith (GENS) e Coordenador de Publicações da AGB-SP.E-mail:<joaosouzacontato@gmail.com>

\section{FERNANDO MOLNAR CASTRO}

Bacharelando em Geografia da Faculdade de Filosofia, Letras e Ciências Humanas da Universidade de São Paulo, Auxiliar Técnico Educacional da Prefeitura Municipal de São Paulo, Coordenador do Grupo de Estudo Neil Smith (GENS). E-mail: <fernando.molnar.castro@usp.br> 